\title{
Editorial: Design and Application of Novel Combustion Systems for Internal Combustion Engines
}

\author{
Stephen Busch* \\ Sandia National Laboratories (SNL), Livermore, CA, United States
}

Keywords: internal combustion engine, carbon neutrality, turbulent jet ignition, combustion system optimization, prechamber combustion concept, flow measurement devices

\section{Editorial on the Research Topic}

Design and Application of Novel Combustion Systems for Internal Combustion Engines

\section{OPEN ACCESS}

Edited by:

Alpaslan Atmanli,

National Defense University, Turkey

Reviewed by:

Emre Aytav,

National Defense University, Turkey

Hamit Solmaz,

Gazi University, Turkey

Francesco Contino,

Catholic University of

Louvain, Belgium

Amin Paykani,

University of Hertfordshire,

United Kingdom

*Correspondence:

Stephen Busch

sbusch@sandia.gov

Specialty section:

This article was submitted to

Engine and Automotive Engineering, a section of the journal

Frontiers in Mechanical Engineering

Received: 04 March 2021

Accepted: 30 March 2021

Published: 27 April 2021

Citation:

Busch S (2021) Editorial: Design and Application of Novel Combustion

Systems for Internal Combustion

Engines. Front. Mech. Eng. 7:676196.

doi: 10.3389/fmech.2021.676196
Efforts to reach worldwide net-zero carbon emissions necessarily include the rapid reduction of carbon emissions associated with transportation sources. Consequently, many countries have already implemented policies banning internal combustion engine powered vehicles within the next two decades. Most passenger vehicle manufacturers have already committed to replacing internal combustion engines with battery-electric powertrains in their passenger car fleets within the next two decades. Scenarios that achieve carbon neutrality assume that by 2050, all but a very small fraction of the light-duty stock will be battery-electric vehicles (BP, 2020; Williams et al., 2021). Heavy-duty truck manufacturers likewise offer fully electric trucks and tractors for short-haul applications, and as many as half of all trucks may need to be at least partially electrified by 2050 to avoid exceeding carbon emission budgets (OECD/IEA, 2017).

The success of this approach at eliminating carbon emissions depends on the degree to which the carbon intensity of the electricity used to produce, operate, and recycle these vehicles can be reduced. Replacing the world's thermal electrical generating capacity with low-carbon sources will require the construction of millions of wind turbines and solar plants, as well as significant new infrastructure for distributing/storing this electricity and systems to manage fluctuations in supply and demand. The most viable approaches to meeting U.S. energy demands while achieving carbon neutrality in the next three decades will result in at least $90 \%$ of electrical generation capacity coming from wind and solar (Williams et al., 2021). While this course of action will be astonishingly resource intensive, some analyses do suggest that it is both technically and economically feasible in much of the world (see, for example, Jacobson et al., 2017). While the efficacy with which governments, private industry, and free markets can realize carbon neutrality remains to be demonstrated and may take much longer than anticipated (Reitz et al., 2020), its necessity will remain as a fundamental driving force.

Because the transition from liquid fuels to low-carbon electricity as the primary source of transportation energy will be a gradual one, internal combustion engines form a logical part of the pathway to zero carbon. Biofuels and e-fuels will play an important role in achieving net-zero carbon emissions (BP, 2020; Williams et al., 2021), and they will be essential for applications in which the use of liquid fuels remains unavoidable. However, the consumption of liquid fuels in a net-zero-carbon scenario is clearly undesirable because of the opportunity cost associated with emitting carbon that could otherwise be sequestered (OECD/IEA, 2017). While electrification will counteract the effects of increased passenger vehicle kilometers traveled, reductions in liquid fuel demand are projected to only be possible through significant improvements in vehicle fuel efficiency (BP, 2020). Such improvements will necessitate some degree of electrification in the form 
of hybrid powertrains (IEA, 2020), but the internal combustion engine is directly linked to the liquid fuel consumed by a hybrid vehicle. Regardless of the source of liquid fuels and the vehicles in which they are consumed, the need for further improvements in engine efficiency remains as urgent as ever. There remains significant scope for improvements in efficiency in internal combustion engines (Leach et al., 2020).

Research and development of engine combustion systems continues to address barriers to significant efficiency improvements; this collection of articles represents a small sampling of these efforts. Prechamber, or turbulent-jet ignition systems promise to overcome several barriers to improved efficiency. In engines that have traditionally employed spark ignition to ignite stoichiometric air/gasoline mixtures, turbulentjet ignition systems can enable lean, dilute operation to reduce fuel consumption by more than $20 \%$. An understanding of the complex interactions between the reacting turbulent jets and the in-cylinder charge is key to the successful development of these systems. Computational fluid dynamics simulations, coupled with genetic algorithms and machine learning techniques, enable efficient optimization of prechamber geometries and analyses of the results provide insight into the key geometric parameters of the prechamber. These advancements in optimization methodology promise to become the new state-of-the-art in combustion system design. In heavy-duty, high-load applications, where diesel engines may be difficult to replace, prechamber combustion systems may enable the

\section{REFERENCES}

BP (2020). Energy Outlook: 2020 Edition. Available online at: https://www.bp. com/en/global/corporate/energy-economics/energy-outlook.html (accessed February 10, 2021).

IEA (2020). Global EV Outlook 2020. Paris: IEA. Available online at: https://www. iea.org/reports/global-ev-outlook-2020 (accessed March 15, 2021).

Jacobson, M. Z., Delucchi, M. A., Bauer, Z. A. F., Goodman, S. C., Chapman, W. E., Cameron, M. A., et al. (2017). 100\% clean and renewable wind, water, and sunlight all-sector energy roadmaps for 139 countries of the world. Joule 1, 108-121. doi: 10.1016/j.joule.2017. 07.005

Leach, F. C. P., Kalghatgi, G., Stone, C. R., and Miles, P. (2020). The scope for improving the efficiency and environmental impact of internal combustion engines. Transp. Eng. 1:100005. doi: 10.1016/j.treng.2020.100005

OECD/IEA (2017). Chapter 2 of Perspectives for the Energy Transition - Investment Needs for a Low-Carbon Energy System (Abu Dhabi: OECD/IEA). use of low-carbon alcohol fuels in high efficiency, mixing controlled combustion systems. Finally, further efficiency gains can be realized with improved control of air and fuel on both a cycle-to-cycle and a cylinder-to-cylinder basis. Indeed, new instrumentation and the data that can be collected with it enable even more accurate models-permitting more efficient engine design in the virtual world. A new technique to measure flow in intake ports has also been developed to inform fast, physics-based models needed for such advanced engine control systems. Jointly, the successful implementation of these technologies will help minimize the consumption of liquid fuels and ensure that low-carbon fuels are usable over a wide range of challenging applications.

\section{AUTHOR CONTRIBUTIONS}

The author confirms being the sole contributor of this work and has approved it for publication.

\section{ACKNOWLEDGMENTS}

Sandia National Laboratories was a multimission laboratory managed and operated by National Technology and Engineering Solutions of Sandia, LLC., a wholly owned subsidiary of Honeywell International, Inc., for the U.S. Department of Energy's National Nuclear Security Administration under contract DE-NA0003525.

Reitz, R. D., Ogawa, H., Payri, R., Fansler, T., Kokjohn, S., Moriyoshi, Y., et al. (2020). IJER editorial: the future of the internal combustion engine. Int. J. Engine Res. 21, 3-10. doi: 10.1177/1468087419877990

Williams, J. H., Jones, R. A., Haley, B., Kwok, G., Hargreaves, J., Farbes, J., et al. (2021). Carbon-neutral pathways for the United States. AGU Adv. 2:e2020AV000284. doi: 10.1029/2020AV000284

Conflict of Interest: The author declares that the research was conducted in the absence of any commercial or financial relationships that could be construed as a potential conflict of interest.

Copyright (C) 2021 Busch. This is an open-access article distributed under the terms of the Creative Commons Attribution License (CC BY). The use, distribution or reproduction in other forums is permitted, provided the original author(s) and the copyright owner(s) are credited and that the original publication in this journal is cited, in accordance with accepted academic practice. No use, distribution or reproduction is permitted which does not comply with these terms. 